\title{
Effects of Amino Acids and Dipeptides on the Uptake and Transport of Iron by Caco-2 Cells Cultured in Serum-Free Medium
}

\author{
Ratchanee KONGKACHUICHAI and Kyoden YASUMOTO* \\ Research Institute for Food Science, Kyoto University, Gokasho, Uji, Kyoto 611, Japan \\ Received January 6, 1997; Accepted May 20, 1997
}

\begin{abstract}
This study was conducted to investigate the effect of five amino acids, aspartic acid, glutamic acid, histidine, cysteine and phenylalanine, and of two dipeptides, anserine and carnosine, on the uptake and transport of iron across monolayers of Caco-2 cells. Caco-2 cells were grown on polycarbonate membrane inserts in serum-free medium [DMEM plus ITS $(5 \mathrm{mg} / l$ insulin, $5 \mathrm{mg} / l$ transferrin and $5 \mu \mathrm{g} / l$ selenious acid)]. The anserine, carnosine, glutamic acid, histidine and aspartic acid, except for cysteine and phenylalanine, at $20 \mu \mathrm{M}$ significantly increased the uptake and transport of iron. Iron uptake and rate of iron transport in the presence of aspartic acid at $20 \mu \mathrm{M}$ were significantly greater than those of other test solutions. When the concentration of added carnosine, anserine, glutamic acid, histidine and phenylalanine was increased from $20 \mu \mathrm{M}$ to $1 \mathrm{mM}$ in the test solution, the uptake and transport of iron was further increased. The results of the present study indicated that aspartic acid, glutamic acid, histidine, and the dipeptides, anserine and carnosine, enhanced the uptake and transport of iron by Caco-2 cells.
\end{abstract}

Keywords: amino acid, Caco-2 cells, iron uptake, transport, carnosine, anserine

Iron deficiency anemia is widely prevalent around the world especially in developing countries (Southeast Asia and Africa) (Paracha et al., 1993). The problem of iron deficiency anemia consequently leads to low immunity function, impaired work performance and mental development in children, and increased maternal mortality (FAO/WHO, 1992). Iron deficiency is primarily prevalent in areas where heme iron, in the form of meat, is less consumed (Flynn et al., 1984). There are several important factors which directly affect the bioavailability of dietary iron. For example, the sources of iron in food, solubility, valence state and complexation behavior (Clydesdale, 1982). It has been suggested that low molecular weight ligands are essential to enhance iron bioavailability because they have the ability to form complexes with iron and retain iron in solution (Flynn et al., 1984). However, amino acids are of special biological interest because they constitute a large ligand pool in the intestinal lumen (Van Campen, 1973). On the other hand, certain amino acids have been found to enhance the iron absorption (Martinez-Torres et al., 1981; Flynn et al., 1984). The ability of amino acids to enhance iron absorption is not yet clear. Some studies have reported that certain amino acids increased iron absorption (Van Campen, 1973; Martinez-Torres et al., 1981; Taylor et al., 1986); whereas, the study of Layrisse et al. (1984) has shown no effect. Previous studies have shown that the animal tissues (meat) and peptides enhance iron absorption and iron uptake (Slatkavitz \& Clydesdale, 1988; Gordon \& Godber, 1989; Kapsokefalou \& Miller, 1991; Garcia et al., 1996; Glahn et al., 1996). Animal muscles are good sources of anserine and carnosine (Susan et al., 1989). Previous reports showed that

* To whom correspondence should be addressed. carnosine was completely hydrolyzed to $\beta$-alanine and histidine, except for anserine which was hydrolyzed by about 86\% (Hama et al., 1976; Ganapathy \& Leibach, 1982). Moreover, we have studied the effects of sugars and aspartame on the uptake and transport of iron by Caco- 2 cells, and the results revealed that aspartame enhanced the uptake and transport of iron by Caco-2 cells. Aspartame is completely hydrolyzed and metabolized in the body to aspartic acid, phenylalanine and methanol, all of which are further metabolized to provide energy in the cells (Ranney \& Oppermann, 1979). Therefore, in this study, we used a cell culture system (Caco-2 cells) to clarify the role of the hydrolysis of aspartame (aspartic acid and phenylalanine), glutamic acid, histidine, cysteine, and dipeptides (anserine and carnosine) on iron uptake and transport by Caco- 2 cells.

\section{Materials and Methods}

Cell culture Caco-2 cells, obtained from the American Type Culture Collection (Rockville, MD, USA) at passage 18, were maintained in Dulbecco's modified Eagle medium (DMEM) supplemented with $10 \%$ fetal bovine serum (FBS; ICN Biomedicals, Inc., OH, USA), $1 \%$ nonessential amino acids (NEAA; Dainippon Pharmaceutical Co., Ltd., Osaka), and $50 \mathrm{U} / \mathrm{ml}$ penicillin-G, $50 \mu \mathrm{g} / \mathrm{ml}$ streptomycin (Dainippon Pharmaceutical Co., Ltd.) and $50 \mu \mathrm{g} / \mathrm{ml}$ gentamycin (Sigma Chemical Co., St. Louis, MO, USA). Serum-free medium consisted of DMEM plus ITS $(5 \mu \mathrm{g} / \mathrm{ml}$ insulin, 5 $\mu \mathrm{g} / \mathrm{ml}$ transferrin, $5 \mathrm{ng} / \mathrm{ml}$ selenious acid), $2 \mathrm{nM}$ triiodothyronine and $100 \mathrm{~nm}$ hydrocortisone (Sigma Chemical Co.). Stock cultures of Caco- 2 cells were seeded at a density $6.7 \times 10^{4}$ cell $/ \mathrm{cm}^{2}$ in petri dishes and incubated at $37^{\circ} \mathrm{C}$ in a humidified atmosphere of $5 \% \mathrm{CO}_{2}$ in air. The medium was changed every 
other day. At 70-80\% confluence, generally 6-7 days after seeding, cells were rinsed in Dulbecco's phosphate buffer without calcium and magnesium (PBS( - ); ICN Biomedicals, Inc.) and then treated for $20 \mathrm{~min}$ with $\mathrm{PBS}(-)$ containing $0.25 \%$ trypsin and $0.54 \mathrm{~mm} \mathrm{Na} \mathrm{Na}_{2}$ ETA. Cells were counted under a light microscope after trypsinization.

For cells cultured under low-iron conditions Caco-2 cells $\left(1 \times 10^{5} \mathrm{cell} / \mathrm{cm}^{2}\right)$ were initially seeded on collagen-treated polycarbonate membrane inserts (each insert had an area of $4.65 \mathrm{~cm}^{2}$ and a pore diameter of $3 \mu \mathrm{m}$; Nippon Becton Dickinson Co., Ltd., Tokyo) and cultured with DMEM that contained 10\% FBS for the first $48 \mathrm{~h}$. This procedure allows cells to firmly attach to the membrane insert via fibronectin, which is present in FBS (Hashimoto \& Shimizu, 1993). After 2 days, DMEM plus FBS was replaced by serum-free medium. Caco- 2 cells were incubated under these conditions for 12-14 days to allow cells to proliferate and mature. Experiments were conducted on day 14 . By this time, Caco-2 cells have consistently been shown to have undergone complete enterocytic differentiation and the polarization of cells monolayers (Hidalgo et al., 1989) and that was also confirmed using scanning electron microscopy (S-4100; Hitachi, Tokyo).

Iron uptake Metal chelate solutions were freshly prepared before each experiment. Stock solutions containing $10 \mathrm{mM} \mathrm{FeCl}_{3} \cdot 6 \mathrm{H}_{2} \mathrm{O}$ plus $10 \mathrm{mM}$ sodium nitrilotriacetate (NTA) were freshly prepared for each experiment. Stock solutions were diluted 10-fold with sterile deionized water before transfer of an appropriate volume to the test solutions (serum-free medium). Ferric nitrilotriacetate ( $\mathrm{Fe}^{3+}$ : NTA) at $10 \mu \mathrm{M}$ was transferred to test solutions containing either an amino acid (glutamic acid, aspartic acid, histidine, cysteine or phenylalanine) or a dipeptide; anserine or carnosine, at final concentrations of $20 \mu \mathrm{M}$ or $1 \mathrm{mM}$. The control test solution contained certain amino acids as contaminants due to the amino acids present in serum-free medium. Each test solution was mixed well and then the $\mathrm{pH}$ was adjusted to 7.0-7.4 with sodium bicarbonate. ${ }^{59} \mathrm{FeCl}_{3}$ (Amersham International, Buckinghamshire, UK) was immediately added to the test solutions to give $1.67 \mathrm{kBq} /$ insert. Before the start of the experiment, each test solution was incubated at $37^{\circ} \mathrm{C}$ for at least $30 \mathrm{~min}$.

Assays of iron uptake Monolayers of Caco-2 cells grown on polycarbonate membrane inserts were washed twice on both sides of the membrane inserts (apical and basal chambers) with prewarmed serum-free medium. Then $1.5 \mathrm{ml}$ of a test solution was added to the upper compartment, and $2.5 \mathrm{ml}$ of serum-free medium was added to the basal compartment. Cells were incubated at $37^{\circ} \mathrm{C}$. At the end of the incubation, the test solution was removed by an aspirator, and the monolayer of cells was washed three times with $2 \mathrm{ml}$ each of ice-cold buffer that contained $150 \mathrm{mM} \mathrm{NaCl}, 1 \mathrm{~mm}$ EDTA, $10 \mathrm{~mm}$ HEPES, $\mathrm{pH} 7$, to remove nonspecifically bound ${ }^{59} \mathrm{FeCl}_{3}$ (Han et al., 1995). The filter with the cell monolayer was then carefully removed from the plastic support, placed in a plastic tube, and $1.0 \mathrm{ml}$ of harvest buffer, which contained $1.7 \mathrm{~mm}$ SDS and $1 \mathrm{mM}$ EDTA, pH 7.0, was added. After sonication, the radioactivity in the harvest buffer with cells was determined with a gamma counter (MINAXI
Auto Gamma 5000; Packard, Meriden, CT, USA). The quantity of iron taken up by cells was calculated from the specific radioactivity of the test solution and is presented as pmol/insert (Halleux \& Schneider, 1994; Han et al., 1995).

To avoid formation of ferric hydroxide polymers which are insoluble in aqueous medium, NTA, amino acids or dipeptides were added in the test solution, and the solubility of iron in test solutions was examined by the method of Han et al. (1994). The molar ratios of $\mathrm{Fe}^{3+}: \mathrm{NTA}$ : amino acid or dipeptide tested were $1: 2: 2,1: 1: 2$ and $1: 0: 2$. The mixtures $(1: 2: 2,1: 1: 2$ and $1: 0: 2)$ left at room temperature for $3 \mathrm{~h}$ were clearly indicating that iron in the test solutions containing NTA plus amino acid or dipeptide remained soluble. Without NTA (molar ratio of $1: 0: 2$ ), iron was rapidly precipitated in the test solution. We determined the effect of different concentrations of nitrilotriacetate (NTA) which complexed with $\mathrm{FeCl}_{3}$ at a molar ratio $1: 2$ and $1: 1$ by measuring the iron uptake in Caco- 2 cells. Results showed that the iron uptake increased by more than $50 \%$ when the molar ratio of $\mathrm{Fe}^{3+}:$ NTA was decreased from $1: 2$ to $1: 1$. It is possible that NTA and amino acid competed in binding with iron or that NTA at a higher concentration inhibited the iron uptake (Raja et al., 1987).

Iron transport The transport assays were initiated in a manner similar to that described for the uptake study. The test solution $(1.5 \mathrm{ml})$ was added to the apical chamber, and $2.5 \mathrm{ml}$ of fresh serum-free medium was added to the basal chamber. The rate of iron transport from the apical to the basal chamber was determined by removing an aliquot $(200 \mu 1)$ of the test solution from the basal chamber after 20,40, and 60 $\mathrm{min}$. An equivalent aliquot of fresh medium was added to the basal chamber after each sampling to maintain the original vol'ume. Iron transport across the monolayer was assessed by determining the radioactivity in the aliquots from the basal chamber with a gamma counter. The quantity of iron transferred from the apical to the basal chamber (Fig. 3 and summarized in Table 1) was estimated from the specific radioactivity of the test solution added to the apical chamber and is presented as $\mathrm{pmol} / \mathrm{cm}^{2} / \mathrm{min}$. The rate of iron transport

Table 1. Rates of iron transport by Caco-2 cells in the presence or absence of amino acids and dipeptides.

\begin{tabular}{lcc}
\hline \multirow{2}{*}{ Test solution } & \multicolumn{3}{c}{ Transport $\left(\mathrm{pmol} / \mathrm{cm}^{2} / \mathrm{min}\right)$} \\
\cline { 2 - 4 } Control & \multicolumn{3}{c}{$20 \mu \mathrm{M}$} & $1 \mathrm{mM}$ \\
Aspartic acid & $0.84 \pm 0.01^{\mathrm{a}}$ & \\
Glutamic acid & $2.09 \pm 0.09^{\mathrm{d}}$ & $1.90 \pm 0.05^{\mathrm{d}}$ \\
Histidine & $1.07 \pm 0.05^{\mathrm{b}}$ & $1.35 \pm 0.06^{\mathrm{c}}$ \\
Phenylalanine & $0.92 \pm 0.06^{\mathrm{a}}$ & $1.17 \pm 0.05^{\mathrm{c}}$ \\
Cysteine & $0.80 \pm 0.15^{\mathrm{a}}$ & $0.87 \pm 0.02^{\mathrm{a}}$ \\
Anserine & $0.73 \pm 0.09^{\mathrm{a}}$ & $0.84 \pm 0.05^{\mathrm{a}}$ \\
Carnosine & $1.02 \pm 0.06^{\mathrm{b}}$ & $1.39 \pm 0.10^{\mathrm{c}}$ \\
\hline
\end{tabular}

Each value represents mean \pm SEM of two experiments with five replicates each. Significant differences between groups are indicated by different superscript at $p<0.05$. The test solution $(1.5 \mathrm{ml})$ which contained $10 \mu \mathrm{M}$ of ferric chloride complexed with NTA at a molar ratio of $1: 1$ and $20 \mu \mathrm{M}$ or $1 \mathrm{mM}$ of amino acid, dipeptides plus $1.67 \mathrm{kBq}{ }^{59} \mathrm{FeCl}_{3}$ /insert was added in the apical chamber and $2.5 \mathrm{ml}$ of medium in the basal chamber and incubated at $37^{\circ} \mathrm{C}$. The amount of radioisotope in the basal chamber was determined at 20,40, and $60 \mathrm{~min}$ as described in Materials and Methods. 
(Fig. 3 and summarized in Table 1) was calculated by linear regression analysis of data from 20 to $60 \mathrm{~min}$ (Halleux \& Schneider, 1994; Han et al., 1995).

Chemicals All amino acids were purchased from Nacalai Tesque Co., Ltd. (Kyoto). Dipeptides were obtained from Sigma Chemical Co.

Statistical analysis All variables were tested using at least six culture inserts for each experiment and each experiment was repeated twice. The iron uptake and transport data were compared using a one-way ANOVA with post hoc comparison by Scheffe's test (Abacus Concepts, Inc., Berkeley, CA, USA).

\section{Results and Discussion}

A human colon adenocarcinoma cell line (Caco-2 cells) has the unique property of spontaneously differentiating on reaching confluence. Caco- 2 cells exhibited many of the structural and functional properties of mature human small intestinal enterocytes such as formation of a brush border membrane with apical microvilli and tight junctions (Hidalgo et al., 1989; Qian \& Tang, 1995). Additionally, they express enterocyte-specific enzymes such as sucrase-isomaltase, aminopeptidase or alkaline phosphatase in their microvilli membrane and hormone receptors (Pinto et al., 1983; Hidalgo et al., 1989; Jumarie \& Malo, 1991). Caco-2 cells grown on a microporous membrane insert have been found to be a useful model for the study on mechanism of uptake and transport of nutrients and drugs (Quick \& Ong, 1990; Artursson \& Karlsson, 1991; Nicklin et al., 1995; Ekmekcioglu et al., 1996; Glahn et al., 1996; Sanchez et al., 1996).

For the above-mentioned characteristics, it is speculated that Caco- 2 cells may be a suitable model for studying the influence of food components on the intestinal uptake and absorption of nutrients. In this study, we evaluated the effects

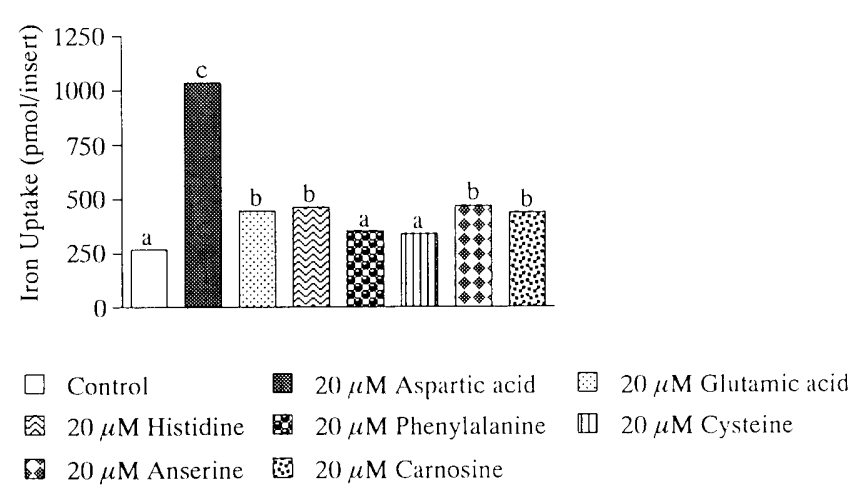

Fig. 1. Effect of aspartic acid, glutamic acid, histidine, phenylalanine, cysteine and dipeptides (anserine and carnosine) on iron uptake by Caco-2 cells. Caco-2 cells were cultured in serum-free medium for 14-18 days post confluence culture. Caco-2 cells were incubated with $1.5 \mathrm{ml}$ of test solutions (which contained $10 \mu \mathrm{M}$ of $\mathrm{FeCl}_{3}$ complexed with $10 \mu \mathrm{M}$ of nitrilotriacetic acid and $20 \mu \mathrm{M}$ of aspartic acid, glutamic acid, histidine, phenylalanine, cysteine, dipeptides (anserine and carnosine) and $1.67 \mathrm{kBq}{ }^{59} \mathrm{FeCl}_{3} /$ insert) in the apical chamber and $2.5 \mathrm{ml}$ of serum-free medium in the basal chamber. Cells were incubated at $37^{\circ} \mathrm{C}$ for $1 \mathrm{~h}$. Each value represents mean $\pm \mathrm{SEM}$ of two experiments with five replicates each. The different letters above the error bars indicate that values are significantly different at $p<0.05$. of amino acids and dipeptides on the uptake and transport of iron in Caco-2 cells.

Effects of aspartic acid and glutamic acid on uptake and transport of iron It is apparent from Figs. 1, 3 and Table 1 that the addition of aspartic acid at $20 \mu \mathrm{M}$ to the test solution significantly enhanced the uptake and increased the transport of iron when compared with other test solutions $(p<0.05)$. However, significant $(p<0.05)$ reduction was observed in the iron uptake when the concentration of aspartic acid in the test solution was increased from $20 \mu \mathrm{M}$ to $1 \mathrm{mM}$ (Fig. 2). At a high concentration of aspartic acid (1 $\mathrm{mM})$, the iron uptake decreased significantly $(p<0.05)$, perhaps due to an inhibition effect of aspartic acid. Of all the amino acids used in this experiment, aspartic acid had the greatest promoting effect on iron uptake and transport by Caco- 2 cells. The mechanism by which aspartic acid enhances the uptake and transport of iron is not clear. It may be that aspartic acid binds with iron and carries it towards the cell membrane receptors responsible for iron uptake and transport (Kroe et al., 1966; Cox \& Peters, 1980; Stefanini et al., 1989). In the previous study, aspartame (a dipeptide) enhanced iron uptake and transport by $\mathrm{Caco}-2$ cells. It has been reported that aspartame is completely hydrolyzed or metabolized to aspartic acid and phenylalanine (Ranney \& Oppermann, 1979; Bertorelli et al., 1990), and therefore, the effect of aspartame observed in our study may be through aspartic acid, one of the components of aspartame.

The effects of glutamic acid on iron uptake and transport of iron by Caco-2 cells The iron uptake and transport of iron by Caco-2 cells were also significantly increased by the addition of $20 \mu \mathrm{M}$ of glutamic acid at $p<0.05$ (Figs. 1, 3 and Table 1). When the concentration of glutamic acid added to the test solution was increased from $20 \mu \mathrm{M}$ to $1 \mathrm{~mm}$ only iron transport was significantly increased at $p<$ 0.05 (Table 1).

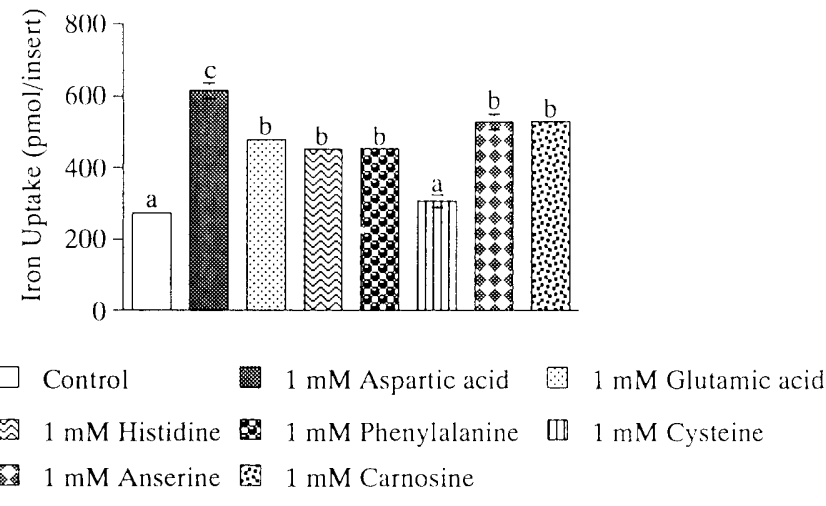

Fig. 2. Effect of aspartic acid, glutamic acid, histidine, phenylalanine, cysteine and dipeptides (anserine and carnosine) on iron uptake by $\mathrm{Caco}-2$ cells. Caco- 2 cells were cultured in serum-free medium for 14-18 days post confluence culture. $\mathrm{Caco}-2$ cells were incubated with $1.5 \mathrm{ml}$ of test solutions (which contained $10 \mu \mathrm{M}$ of $\mathrm{FeCl}_{3}$ complexed with $10 \mu \mathrm{M}$ of nitrilotriacetic acid and $1 \mathrm{~mm}$ of aspartic acid, glutamic acid, histidine, phenylalanine, cysteine, dipeptides (anserine and carnosine) and $1.67 \mathrm{kBq}{ }^{59} \mathrm{FeCl}_{3} /$ insert) in the apical chamber and $2.5 \mathrm{ml}$ of serum-free medium in the basal chamber. Cells were incubated at $37^{\circ} \mathrm{C}$ for $1 \mathrm{~h}$. Each value represents mean \pm SEM of two experiments with five replicates each. The different letters above the error bars indicate that values are significantly different at $p<0.05$ 

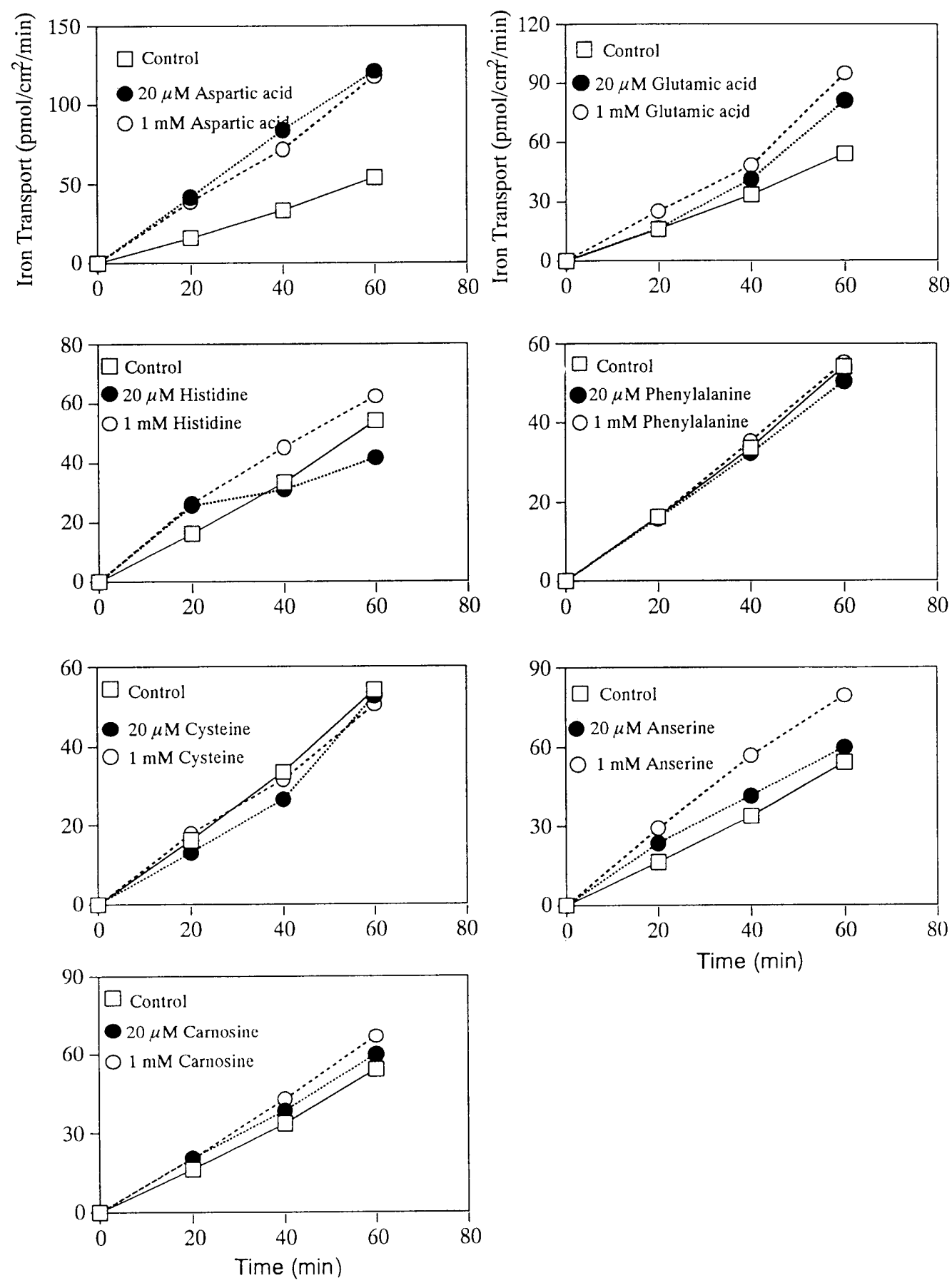

Fig. 3. Effect of aspartic acid, glutamic acid, histidine, phenylalanine, cysteine and dipeptides (anserine and carnosine) on iron transport across monolayers of Caco-2 cells. Test solution ( $1.5 \mathrm{ml}$ ) containing $10 \mu \mathrm{M}$ of $\mathrm{FeCl}_{3}$ complexed with $10 \mu \mathrm{M}$ of nitrilotriacetic acid and either $20 \mu \mathrm{M}$ or $1 \mathrm{mM}$ of aspartic acid, glutamic acid, histidine, phenylalanine, cysteine, dipeptides (anserine and carnosine) and $1.67 \mathrm{kBq}{ }^{59} \mathrm{FeCl}_{3} /$ insert was added to the apical chamber of $14-18$ days post confluent cultures of Caco-2 grown on microporous inserts and $2.5 \mathrm{ml}$ of serum-free medium was added to the basal chamber. Cells were incubated at $37^{\circ} \mathrm{C}$, and the quantity of ${ }^{59} \mathrm{Fe}$ transferred into serum-free medium $(2.5 \mathrm{ml})$ in the basal chamber was monitored periodically for up to 60 min. Symbols are mean values of two experiments with five replicates each.

The effects of histidine on iron uptake and transport of iron by Caco-2 cells As shown in Figs. 1, 2, 3 and Table 1 , the addition of $20 \mu \mathrm{M}$ of histidine to the test solution significantly increased iron uptake over that of the control. When the concentration of histidine in the test solution was increased from $20 \mu \mathrm{M}$ to $1 \mathrm{mM}$, the iron uptake was slightly increased, but the rate of iron transport was significantly increased (Fig. 3 and Table 1). The results of this study were consistent with the observation of Martinez-Torres et al. (1981) who suggested that basic amino acids, aromatic and aliphatic amino acids increased the utilization of nonheme iron. Van Campen in 1973 observed the same findings with histidine and lysine and further suggested that the enhancing effect of histidine and lysine is due to their ability to form tridentate chelates and stable complexes of octahedral configuration of ferric ion and retain iron in soluble form. 
However, these findings differ from those of Layrisse et al. (1984) who found that increasing the doses of histidine from 416 to $2080 \mathrm{mg}$ did not enhance the absorption of corn iron. The differences in observation among these studies may be related to the differences in the sources of iron and the method used.

Effects of cysteine on uptake and transport of iron by Caco-2 cells Previous reports showed that cysteine (a sulfur-containing amino acid) effectively enhances nonheme and heme iron absorption (Layrisse et al., 1984; Kapsokefalou \& Miller, 1991). However, the results of our study showed that both the concentrations $(20 \mu \mathrm{M}$ and $1 \mathrm{mM})$ in the test solution did not influence the iron uptake or transport of iron by Caco-2 cells (Figs. 1, 2, 3 and Table 1). These results agree with Politz and Clydesdale (1988) and Wien and Van Campen (1991) who found that cysteine did not enhance iron absorption. This result was probably due to the unstable nature of cysteine at neutral or alkaline $\mathrm{pH}$, which is rapidly oxidized to cystine. It has been reported that cystine by nature does not enhance iron absorption (Layrisse et al., 1984). Taylor et al. (1986) and Wien and Van Campen (1991) also suggested that the enhancing effect of cysteine on nonheme iron absorption is due to cysteine-containing peptides, which play a role in reducing $\mathrm{Fe}(\mathrm{III})$ to $\mathrm{Fe}(\mathrm{II})$ in the intestinal lumen.

Effects of phenylalanine on uptake and transport of iron Figures 1, 3 and Table 1 showed that no significant increase was observed in the iron uptake and rate of iron transport by Caco- 2 cells at $20 \mu \mathrm{M}$ of phenylalanine in the test solution. When the concentration of phenylalanine in the test solution was increased from $20 \mu \mathrm{M}$ to $1 \mathrm{mM}$, the iron uptake was significantly increased (Fig. 2). However, no significant stimulation was observed in the iron transport (Fig. 3 and Table 1). Phenylalanine is an aromatic amino acid which has no electron charge. Politz and Clydesdale (1988) suggested that the formation of chelates in which the iron combines with electron-donating ligands can solubilize the iron and could prevent or delay hydrolysis and polymerization reactions which would otherwise occur. For this reason, phenylalanine showed a low ability to enhance the iron uptake and transport of iron by Caco-2 cells.

Effects of anserine and carnosine on uptake and transport of iron by Caco-2 cells We observed that addition of anserine or carnosine at $20 \mu \mathrm{M}$ to the test solution significantly increased the iron uptake and stimulated the rate of iron transport at $p<0.05$ (Figs. 1, 2, 3 and Table 1). When the concentrations of anserine or carnosine in the test solution were increased from $20 \mu \mathrm{M}$ to $1 \mathrm{mM}$, only the transportation of iron was further significantly increased $(p<0.05)$ in the case of anserine (Figs. 2, 3 and Table 1). Meat muscles are good sources of carnosine and anserine (Susan et al., 1989). Previous investigators have suggested that amino acids or peptides which are released during meat digestion may be involved in enhancing iron absorption (Kane \& Miller, 1984; Slatkavitz \& Clydesdale, 1988). Our findings suggested that carnosine or anserine may be involved in stimulating iron uptake and rate of iron transport in Caco-2 cells. As far as we know, no study has been conducted on the effects of carnosine or anserine on iron absorption in humans or animals. The results presented in this study conclude that the supplementation of certain amino acids and dipeptides in foods may improve the absorption and utilization of iron. Further investigation is needed to reveal the effects of carnosine and anserine in the diet on iron absorption in humans.

Acknowledgments The authors are grateful to Dr. Kazumi Saito, Professor at Kyoto Prefectural University and Dr. Fumito Tani, Instructor at the Research Institute for Food Science, Kyoto University, for their valuable suggestions. Special thanks are due to the staff of the Radioisotope Research Center at Kyoto University for allowing us to use the facility for conducting this study. This work was supported by the National Dairy Promotion and Research Association.

\section{References}

Artursson, P. and Karlsson, J. (1991). Correlation between oral drug absorption in humans and apparent drug permeability coefficients in human intestinal epithelial (Caco-2) cells. Biochem. Biophys. Res. Commun., 175, 880-885.

Bertorelli, A.M. and Czarnowski-Hill, J.V. (1990). Review of present and future use of nonnutritive sweeteners. Diabetes Educ., 16, 415422.

Clydesdale, F.M. (1982). The effects of some physiochemical properties of food on the chemical status of iron. In "Nutritional Bioavailability of Iron," ed. by C. Kies. ACS symposium series, No. 203. American Chemical Society, Washington, D.C., pp. 58-84

Cox, T.M. and Peters, T.J. (1980). Cellular mechanisms in the regulation of iron absorption by the human intestine: Studies in patients with iron deficiency before and after treatment. Br. J. Haematol., 44, 75-86.

Ekmekcioglu, C., Feyertag, J. and Marktl, W. (1996). A ferric reductase activity is found in brush border membrane vesicles isolated from Caco-2 cells. J. Nutr., 126, 2209-2217.

FAO/WHO (1992) International conference on nutrition. Nutrition and development of a global assessment. Micronutrient deficiencies and preventing specific micronutrient deficiencies. FAO, Rome, Italy.

Flynn, S.M., Clydesdale, F.M. and Zajicek, O.T. (1984). Complexation, stability and behavior of L-cysteine and L-lysine with different iron sources. J. Food Prot., 47, 36-40.

Ganapathy, V. and Leibach, F.H. (1982). Peptide transport in rabbit kidney studies with L-carnosine. Biochim. Biophys. Acta, 691, 362 366.

Garcia, M.N., Flowers, C. and Cook, J.D. (1996). The Caco-2 cell culture system can be used as a model to study food iron availability. J. Nutr., 126, 251-258.

Glahn, R.P., Wien, E.M. and Van Campen, D.R. (1996). Caco-2 cells iron uptake from meat and casein digests parallels in vivo studies: use of a novel in vitro method for rapid estimation of iron bioavailability. J. Nutr., 126, 332-339.

Gordon, D.T. and Godber, J.S. (1989). The enhancement of nonheme iron bioavailability by beef protein in the rats. J. Nutr., 119, 446 452.

Halleux, C. and Schneider, Y.J. (1994). Iron absorption by Caco-2 cells cultivated in serum-free medium as in vitro model of the human intestinal epithelial barrier. J. Cell. Physiol., 158, 17-28.

Hama, T., Tamaki, N., Miyamoto, F., Kita, M. and Tsunemori, F. (1976). Intestinal absorption of $\beta$-alanine, anserine and carnosine in rats. J. Nutr. Sci. Vitaminol., 22, 147-157.

Han, O., Failla, M.L., Hill, A.D., Morris, E.R. and Smith, J.C., Jr. (1994). Inositol phosphates inhibit uptake and transport of iron and zinc by a human intestinal cell line. J. Nutr., 124, 580-587.

Han, O., Failla, M.L., Hill, D., Morris, E.R. and Smith, J.C., Jr. (1995). Reduction of $\mathrm{Fe}$ (III) is required for uptake of nonheme iron by Caco-2 cells. J. Nutr., 125, 1291-1299.

Hashimoto, K. and Shimizu, M. (1993). Epithelial properties of human intestinal Caco-2 cells cultured in a serum-free medium. Cytotechnology, 13, 175-184.

Hidalgo, I.J., Raub, T.J. and Borchardt, R.T. (1989). Characterization 
of the human colon carcinoma cell line (Caco-2) as a model system for intestinal epithelial permeability. Gastroenterology, 96, 736-749.

Jumarie, C. and Malo, C. (1991). Caco-2 cells cultured in serum-free medium as a model for the study of enterocytic differentiation in vitro. J. Cell. Physiol., 149, 24-33.

Kane, A.P. and Miller, D.D. (1984). In vitro estimation of the effects of selected proteins on iron bioavailability. Am. J. Clin. Nutr., 39. 393-401.

Kapsokefalou, A. and Miller, D.D. (1991). Effects of meat and selected food components on the valence of nonheme iron during in vitro digestion. J. Food Sci., 56, 352-358.

Kroe, D.J., Kaufman, N., Klavins, J.V. and Kinney, T.D. (1966). Interrelation of amino acids and $\mathrm{pH}$ on intestinal iron absorption. Am. J. Physiol., 211, 414-419.

Layrisse, M., Martinez-Torres, C., Leets, L., Taylor, P. and Ramirez, J. (1984). Effect of histidine, cysteine, glutamine or beef on iron absorption in human. J. Nutr., 114, 217-223.

Martinez-Torres, C., Romano, E. and Layrisse, M. (1981). Effect of cysteine on iron absorption in man. Am. J. Clin. Nutr., 34, 322-327.

Nicklin, P.L., Irwin, W.J., Hassan, I.F., Mackay, M. and Dixon, H.B. F. (1995). The transport of acidic amino acids and their analogues across monolayers of human intestinal absorptive (Caco-2) cells in vitro. Biochim. Biophys. Acta, 1269, 176-186.

Paracha, P.I., Khan, S.M., Ahmad, I. and Nawab, G. (1993). Effect of iron supplementation on biochemical indices of iron status in selected pre-adolescent schoolgirls in North West Frontier Province, Pakistan. Asia Pac. J. Clin. Nutr., 2, 177-181.

Pinto, M., Robine-Leon, S., Appay, M., Kedinger, M., Triadou, N.J. and Zweibaum, A. (1983). Enterocyte-like differentiation and polarization of the human colon carcinoma cell line $\mathrm{Caco}-2$ cell culture. Biol. Cell., 47, 323-333.

Politz, M.L. and Clydesdale, F.M. (1988). Effect of enzymatic digestion, $\mathrm{pH}$ and molecular weight on the iron solubilization properties of chicken muscle. J. Food Sci., 53, 1081-1090.
Qian, Z.M. and Tang, P.L. (1995). Mechanism of iron uptake by mammalian cells. Biochim. Biophys. Acta, 1269, 205-214.

Quick, T.C. and Ong, D.E. (1990). Vitamin A metabolism in the human intestinal Caco-2 cell line. Biochemistry, 29, 11116-11123.

Raja, K.B., Simpson, R.J. and Peters, T.J. (1987). Effect of $\mathrm{Ca}^{2+}$ and $\mathrm{Mg}^{2+}$ on the uptake of $\mathrm{Fe}^{3+}$ by mouse intestinal mucosa. Biochim. Biophys. Acta, 923, 46-51.

Ranney, R.E. and Oppermann, J.A. (1979). A review of metabolism of the aspartyl moiety of aspartame in experimental animals and man. J. Environ. Pathol. Toxicol., 2, 979-985.

Sanchez, L., Ismail, M., Liew, F.Y. and Brock, J.H. (1996). Iron transport across Caco-2 cell monolayers. Effect of transferrin, lactoferrin and nitric oxide. Biochim. Biophys. Acta, 1289, 291-297.

Slatkavitz, C.A. and Clydesdale, F.M. (1988). Solubility of inorganic iron as affected by proteolytic digestion. Am. J. Clin. Nutr., 47, 487495

Stefanini, S., Desideri, A., Vecchini, P., Drakenberg, T. and Chiancone, E. (1989). Identification of the iron entry channels in apoferritin. Chemical modification and spectroscopic studies. Biochemistry, 28, 378-382.

Susan, B., O'Neil, M.J., Smith, A. and Heckelman, P.E. (1989). The Merck Index. An encyclopedia of chemicals, drugs and biologicals, 11 th ed. Merck, Co., Inc., Rahway, New Jersey, USA, pp. 107, 281. Taylor, P.E., Martinez-Torres, M.A., Romano, E.L. and Layrisse, M. (1986). The effect of cysteine-containing peptides released during meat digestion on iron absorption in human. Am. J. Clin. Nutr., 43, $68-71$.

Van Campen, D.R. (1973). Enhancement of iron absorption from ligated segments of rats intestine by histidine, cysteine and lysine: Effects of removing ionizing groups and of stereoisomerism. $J$. Nutr., 103, 139-142.

Wien, E.M. and Van Campen, D.R. (1991). Ferric iron absorption in rats: Relationship to iron status, endogenous sulfhydryl and other redox components in the intestinal lumen. J. Nutr., 121, 825-831. 